\title{
Historiadores sudamericanos (de habla española): debates e intercambios entre centro y periferia, circa 1840-1940*
}

\author{
Historians in Spanish South America: Debates and Cross \\ References between Centre and Periphery, circa 1840-1940 \\ Historiadores (de fala espanhol) em Sul América hispana: \\ Debates e intercâmbios entre centro e periferia, circa 1840-1940 \\ Juan Maiguashca \\ York University, Toronto (Canadá) / \\ Universidad Andina Simón Bolivar, Sede Ecuador \\ raffael@yorku.ca
}

DOI: http: / / dx.doi.org/10.29078/rp.v0i47.679

* Capítulo publicado originalmente como "Historians in Spanish South America: Cross-References between Centre and Periphery". En The Oxford History of Historical Writing, 1800-1945, ed. por Stuart Macintyre, Juan Maiguashca y Atilla Pók, vol. 4, 463-487 (Oxford: Oxford University Press, 2011). Traducción al castellano de Patrick Saari. Revisión de Guillermo Bustos y Santiago Cabrera Hanna.

Nota del editor: Originalmente, los editores del volumen dividieron América Latina en tres regiones: México, Brasil y América del Sur de habla española. David Brading, C. F. Cardoso y Juan Maiguashca fueron encargados de cada una de ellas, respectivamente.. 
El artículo estudia los procesos de institucionalización y profesionalización de la disciplina histórica en la región sudamericana de habla española, entre circa 1840 y 1940. Contiene tres partes. La primera examina algunos debates sobre la cuestión de cómo escribir la historia. La segunda parte explora el tipo de relato que estos historiadores elaboraron y cómo esta tarea contribuyó a la institucionalización del saber histórico y a la formación de la nación. En la tercera parte, usando Argentina como caso de estudio, se analiza

la profesionalización de la disciplina histórica durante el primer cuarto de siglo XX.

Palabras clave: historia intelectual, historiografía, Sudamérica, siglo XIX, siglo XX, profesionalización de la historia, historiadores.

ABSTRACT

This article studies the processes of institutionalization and professionalization of history as an academic discipline in Spanish South America between circa 1840's and 1940's. It has three parts. The first, examines some debates around the question on how to write Latin American History. The second part explores the kind of national narrative South American historians actually wrote and how this writing contributed both to the institutionalization of historical knowledge and the formation of the national identity. The third part, using Argentine as a case study, analyses the professionalization of history as an academic discipline in the first quarter of the 20th century.

Keywords: Intellectual History, Historiography, South America, 19th Century, 20th Century, professionalization of History, historians.

RESUMO

O artigo faz uma analise dos processos de institucionalização e profissionalização da disciplina histórica na América do sul de fala espanhol, entre ca. 1840 e 1940. Tem três partes. Na primeira, examinam-se algum dos debates produzidos sobre as maneiras de escrever historia. A segunda parte do texto faz uma exploração do tipo da narração nacional que os historiadores sul americanos elaboraram, e como esse empreendimento contribuiu tanto para a institucionalização como para a formação da nação. Na terça parte, utilizando a Argentina como caso de estudo, o artigo oferece uma análise da profissionalização da disciplina histórica no primeiro quarto do século XX.

Palavras chave: Historia intelectual, Escrita da História, América do Sul, século XIX, século XX, historiadores, profissionalização 
El propósito del presente ensayo es ofrecer una idea general de la historiografía de los países sudamericanos de habla española durante el siglo XIX y la primera mitad del siglo XX. No se analiza a los nueve países de forma individual, sino que se considera a la región en conjunto, como una unidad de análisis. ${ }^{1}$ Esto es posible debido a que durante el período referido surgió en esta parte de las Américas un mercado común intelectual, una república de las letras, cuya dimensión y complejidad creció con el tiempo. Como se sabe, también hubo un intercambio de ideas y productos intelectuales durante el período colonial tardío. No obstante, su densidad aumentó luego de la Independencia e incluyó nuevos temas: políticos, militares, económicos, literarios e historiográficos. Este ensayo trata exclusivamente de los últimos.

La idea de un mercado común de escritura historiográfica fue sugerida, pero no desarrollada, por Germán Colmenares en su libro Las convenciones contra la cultura: Ensayos sobre la historiografía hispanoamericana del siglo XIX (1987). En esta obra escribe:

Los historiadores hispanoamericanos se referían constantemente a los europeos. Todos tenían acceso a los mismos autores, casi siempre franceses [...] Pero entre ellos mismos había también referencias cruzadas. Nexos ideológicos, afinidades generacionales, exilios, experiencias históricas comunes o incompatibilidades, reales o supuestas, invitaban a tales referencias. ${ }^{2}$

Más recientemente, Josep Barnadas se ha referido a estas relaciones en forma más enfática: "se debe recordar [escribe], algo que generalmente ha sido olvidado: las relaciones intelectuales, políticas y económicas que las elites hispanoamericanas cultivaron entre sí, fueron mucho más intensas que las que tuvieron con las de Europa o los Estados Unidos". ${ }^{3}$ A continuación ampliaré y desarrollaré la idea de intercambios internos para estudiar a los historiadores sudamericanos desde una nueva óptica.

Desde esta perspectiva, la república de las letras en Sudamérica no fue un terreno parejo. Desde muy temprano, en el siglo XIX, hubo dos centros

1. Los países incluidos en el análisis son: Argentina, Uruguay, Paraguay, Chile, Bolivia, Perú, Ecuador, Colombia y Venezuela.

2. Germán Colmenares, Las convenciones contra la cultura: Ensayos sobre la historiografía hispanoamericana del siglo XIX (Bogotá: Tercer Mundo / Universidad del Valle / Banco de la República, 1987), 41-42, 102-103.

3. Josep Barnadas, Gabriel René Moreno (1836-1908): Drama y gloria de un boliviano (La Paz: Altiplano, 1988), 68. Véase también Jack Ray Thomas, "The Role of Private Libraries and Public Archives in Nineteenth-Century Spanish American Historiography", The Journal of Library History 9, n. ${ }^{\circ} 4$ (1974): 335-351. 
de creación y difusión de producción histórica que superaron a los demás: Santiago en Chile y Buenos Aires en Argentina. Si bien eran las capitales de dos países diferentes, deberían ser consideradas como una sola entidad porque estaban estrechamente interconectadas en términos intelectuales. No dispongo de suficiente espacio para explicar en detalle cómo surgieron estos lazos. Baste decir que la crónica inestabilidad política en Argentina obligó a toda una generación de intelectuales jóvenes a exiliarse en Chile, un país que se encontraba en el proceso de organizar un orden político sorprendentemente estable. Debido a que llegaron precedidos de una gran reputación intelectual, no tardaron en ser invitados por el gobierno chileno a contribuir en numerosas iniciativas en los campos políticos y culturales. Así, la nación anfitriona les permitió no solamente ganarse la vida, sino también publicar obras innovadoras en los campos de la política, el derecho, la literatura y la historia. Durante las décadas de 1830 y 1840 se desarrolló un estrecho vínculo entre intelectuales chilenos y argentinos, colaboración que perduró aún después de que estos últimos regresaron definitivamente a su patria. ${ }^{4}$

Es evidente que el Cono Sur fue considerado un gran centro cultural porque numerosos letrados procedentes de Venezuela, Colombia, Ecuador, Perú y Bolivia coincidieron primero en Santiago y luego en Buenos Aires, ya sea por voluntad propia o debido a que fueron obligados a exiliarse por los regímenes de sus países de origen. ${ }^{5}$ Refiriéndose a Gabriel René Moreno, el historiador boliviano más destacado del siglo XIX, Barnadas escribe: “Chile funcionó como refugio para muchos argentinos, bolivianos y peruanos, así como colombianos y hasta centroamericanos; debido a que Moreno lo había adoptado como su segunda patria, podemos afirmar que él se radicó en el epicentro cultural más importante del continente". ${ }^{6}$ La palabra "centro" utilizada en el título de este ensayo no alude a Europa, sino a un polo de desarrollo intelectual local que

4. Sol Serrano, "Emigrados argentinos en Chile (1840-1855)". En Nueva mirada a la historia, ed. por Esther Edwards (Santiago / Buenos Aires: Ver, 1996), 111-126. Véase también María Sáenz Quesada, "De la Independencia política a la emancipación cultural”. En Ibíd., 91-105; y Rosendo Fraga, "Argentina y Chile entre los siglos XIX y XX (1892-1904)”. En Ibíd., 143-165.

5. Barnadas, Gabriel René Moreno..., 68. Para el surgimiento del Cono Sur como centro cultural, véase Daniel Larriqueta, "Chile y Argentina: indianos diferentes". En Nueva mirada a la historia...; Jeremy Adelman, Republic of Capital: Buenos Aires and the Legal Transformation of the Atlantic World (Stanford: Stanford University Press, 1999); José Moya, "Modernization, Modernity and Trans / Formation of the Atlantic World in the Nineteenth Century". En The Atlantic in Global History, 1500-2000, ed. por Jorge Cañizares-Esguerra y Erik R. Seeman (Upper Sadle River: Pearson Prentice Hall, 2007); y Lyman L. Johnson y Zephyr Frank, "Cities and Wealth in the South Atlantic: Buenos Aires and Rio de Janeiro before 1960", Comparative Studies of Society and History 48, n. 3 (2006): 634-668.

6. Barnadas, Gabriel René Moreno..., 68. 
desde 1840 generó un campo de fuerza, cuya influencia se irradió a toda la región sudamericana de habla española hasta las primeras décadas del siglo XX. Se acostumbra pensar las relaciones entre centro y periferia como si fueran fundamentalmente de explotación. No obstante, este no fue el caso. En su lugar hubo, por lo general, relaciones de colaboración. El "centro", por lo tanto, se refiere a la producción de los historiadores del Cono Sur, entre los decenios de 1840 y 1940, mientras que la "periferia" incluye a la producción del resto de historiadores de la región de estudio, en la medida en que se relacionaban con los desarrollos historiográficos alcanzados en Santiago y Buenos Aires.

Dos cosas se han afirmado como lugar común sobre la historiografía sudamericana decimonónica y de principios del siglo XX. En primer lugar, que se enfocaba en los poderosos y que estaba elaborada por y para ellos. En segundo lugar, que era poco original porque tomaba prestados sus marcos conceptuales de los historiadores europeos. ${ }^{7}$ No voy a poner en tela de juicio la primera afirmación, aunque debo insistir en las siguientes salvedades. Para empezar, esta caracterización se aplica no solo a la historiografía sudamericana, sino también a la de Europa en el siglo XIX. Tampoco se debe olvidar que algunos historiadores sudamericanos se preocuparon y escribieron sobre los amerindios. Los más eruditos e influyentes fueron Vicente Fidel López con su Les races aryennes du Pérou: leur langue, leur religion, leur histoire [Las Razas Arias del Perú: Su Lengua, Su Religión y Su Historia] (1871) y Sebastián Lorente con su Historia de la civilización peruana (1879). En su conjunto, sin embargo, hay que admitir que el inmenso corpus de la historiografía producida durante el lapso de estudio fue escrito en español por autores blancos que reflejaron la cosmovisión del criollo. ${ }^{8}$

7. Véase, por ejemplo, E. Bradford Burns, "Capítulo 3". En The Poverty of Progress: Latin America in the Nineteenth Century (Berkeley: University of California Press, 1983); Colmenares, Las convenciones contra la cultura..., 13, 27, 137; y, más recientemente, Ana Ribeiro, Historiografía Nacional, 1880-1940: De la épica al ensayo sociológico (Montevideo: Ediciones de La Plaza, 1994), 15.

8. En la primera mitad del siglo XIX, un pequeño grupo de autores indígenas intentaron presentar sus propias perspectivas, pero según mi entender y saber no existe nada comparable para el resto de la época. Eso constituye la principal razón de por qué no aparecen obras de autores amerindios en el presente capítulo. Véase Vicente Pazos Kanki, Memorias histórico-políticas (Londres: impreso para el autor, 1834); y Justo Apu Shuaraura, Recuerdos de la Monarquía peruana o bosquejo de la historia de los Incas (París: Imprenta de J. Claye, 1850). La primera obra es un esfuerzo de varios tomos que nunca se finalizó, realizado por un aymara boliviano quien se había convertido en un fervoroso republicano. La segunda, en lugar de un texto histórico, es una genealogía de los emperadores incas, recopilada por un sacerdote de descendencia incásica. Se ha sugerido que su propósito habría sido presentarse a sí mismo como una persona que hubiera podido restaurar la monarquía inca en el Perú. Al respecto véase Catherine Julien, "Recuerdos de la monarquía peruana", Hispanic American Historical Review 84, n. ${ }^{\circ}$ (2004): 344-345. 
En cuanto a la segunda afirmación, la idea de que los historiadores sudamericanos eran "imitadores" de modelos extranjeros, víctimas de lo que J. M. Blaut denomina el "difusionismo europeo", refleja una creencia profundamente arraigada, a saber: que los pueblos europeos fueron creadores del conocimiento histórico (como de otros saberes) y que los no europeos, incluso los latinoamericanos, simplemente los adoptaron con modificaciones menores. ${ }^{9}$ Creo que se debe cuestionar esta interpretación. Los historiadores sudamericanos no solo fueron consumidores de ideas extranjeras, también fueron innovadores. Además de ofrecer una idea general acerca de la historiografía sudamericana, este estudio también presenta pruebas para sustentar lo dicho.

Para cumplir con estos dos objetivos, el ensayo se divide en tres partes. En la primera, examina tres debates del siglo XIX desarrollados en el Cono Sur acerca de cómo se debía escribir la historia de las nuevas repúblicas. Estos debates tuvieron dos consecuencias: la institucionalización de la historiografía en la región y la selección de herramientas que permitían captar su realidad histórica en forma innovadora. En la segunda parte, se pasa de método a contenido y se identifica la creatividad de los historiadores objeto de estudio en la escritura de sus respectivas historias nacionales. Finalmente, en la tercera parte, utilizando a Argentina como ejemplo, se examina cómo empezó a desarrollarse la profesionalización de la historia en la primera mitad del siglo XX. Lo que sucedió en Argentina aconteció en el resto de la región más tarde y en menor medida.

\section{CÓMO SE DEBERÍA ESCRIBIR LA HISTORIA DE LAS REPÚBLICAS SUDAMERICANAS, 1840-1910}

Aparte de Charles Darwin, el extranjero más eminente que llegó a Chile en el siglo XIX fue Andrés Bello, un venezolano, quien asumió funciones en la administración pública del gobierno chileno en 1829 y dedicó el resto de su vida a esta tarea. Erudito polivalente, Bello alcanzó la cúspide de su potencial en las décadas de 1840 y 1850, lapso en el cual convirtió a Santiago en un centro de estudios históricos de rango continental. Entre muchas otras cosas, organizó un sistema de educación que dio importancia al estudio del pasado y se dedicó a formar directa e indirectamente a la primera generación de historiadores chilenos y argentinos, iniciando debates públicos sobre cómo escribir la historia de Chile y, por extensión, la del resto de las nacio-

9. J. M. Blaut, The Colonizer's Model of the World: Geographical Diffusionism and Eurocentric History (Nueva York: Guilford, 1993), 8-17. 
nes hispanoamericanas. ${ }^{10}$ Como veremos adelante, estos debates tuvieron un amplio impacto en la historiografía de toda la región.

En 1844, la Universidad de Chile, bajo la rectoría de Bello, estableció un concurso anual invitando a sus docentes a presentar una monografía sobre un tema de la historia nacional. Las Memorias resultantes, publicadas con bastante regularidad entre 1844 y 1918, provocaron un gran número de relevantes debates. ${ }^{11}$ El más célebre de ellos involucró a Bello y a José Victorino Lastarria, un discípulo suyo incorporado recientemente en la facultad. Respondiendo a la pregunta: “Cómo se debería escribir la historia de Chile?”, Lastarria presentó un ensayo con el título de Investigaciones sobre la influencia social de la conquista y del sistema colonial de los españoles en Chile, que desafiaba abiertamente los puntos de vista del rector sobre historiografía. Bello respondió y pronto los círculos intelectuales presenciaron una controversia que duró décadas, primero en Santiago y luego en Buenos Aires. En resumen, el debate oponía aquellos que promovían una historia narrativa (ad narrandum) frente a otros que defendían una historia explicativa (ad probandum). Bello encabezaba el primero de estos grupos y Lastarria el segundo.

Para Bello, la primera tarea del historiador en una nueva nación como Chile era organizar archivos públicos y bibliotecas y someter las fuentes recolectadas a un estudio crítico. Una vez establecida su autenticidad, el paso siguiente era estudiar su significado por medio de una variedad de métodos cognitivos, siendo el método filológico-crítico uno entre otros. Solo entonces el historiador podía utilizar las fuentes para armar una narrativa cronológica, cuya orientación se encontraría en los documentos mismos. Mientras tanto, cualquier investigación de historia que se escribiera tenía que ser considerada como provisional y sujeta a correcciones de contenido y método. Para transmitir al lector la importancia de las fuentes primarias, Bello propuso insertar documentos originales en la narrativa. Ya que no era solamente una cuestión de veracidad, resultó de igual importancia permitir que el lector comprendiera la singularidad del momento y la experiencia vivida. El objetivo final era captar el proceso histórico chileno desde adentro, con el menor número de distorsiones posibles. Solo este tipo de historiografía, sostenía Bello, podía conseguir saberes confiables sobre el pueblo chileno, su tierra y su época, sin los cuales la construcción de una nueva nación era imposible. ${ }^{12}$

10. Iván Jaksić, “Capítulo 2" y “Capítulo 5". En Andrés Bello: Scholarship and Nation Building in Nineteenth-Century Latin America (Cambridge: Cambridge University Press, 2001).

11. Cristián Gazmuri, “Capítulo 4". En La historiografía chilena, 1842-1920 (Santiago: Centro de Investigaciones Diego Barros Arana, 2006).

12. Andrés Bello, Selected Writings of Andrés Bello, ed. por Iván Jaksić (Oxford: Oxford University Press, 1997), 154-184. 
Para Lastarria, en cambio, la historia no era un relato de la totalidad de los hechos, sino solo de los más importantes: de ahí la necesidad de contar con criterios para escoger los que mejor sirvieran para proponer una explicación general. Afirmaba que los hechos tenían significado histórico únicamente cuando daban pruebas del avance del progreso de la humanidad. Dando la espalda a los románticos franceses, prefería el enfoque de la historia planteado por Voltaire en el siglo anterior y por François Guizot, su contemporáneo. Se trataba de una historia interpretativa cuya meta era el despliegue de la civilización no solamente en Europa sino en el mundo entero. Lastarria afirmaba que este tipo de historia era necesaria para Chile y las nuevas naciones de Hispanoamérica porque, después de haber roto las cadenas del colonialismo, todas estaban en búsqueda de la modernidad. No bastaba, entonces, que la historia reconstruyera el pasado tal como sucedió y en toda su plenitud, era aún más importante promover un futuro republicano, aprendiendo de los avances realizados en otras partes. ${ }^{13}$

Después de la primera discusión, otras personas intervinieron y agregaron matices al debate. El mismo Bello agregó algunos puntos que conviene subrayar. Primero, declaró que ambos métodos, ad narrandum y ad probandum, podían ser provechosos en un país que contara con una historiografía ya desarrollada, pero no en Chile, donde todavía no existía la institución de la historia. En tales circunstancias, el método narrativo era un primer paso esencial. Segundo, aconsejó a los jóvenes chilenos que no imiten a Europa servilmente. “¡Jóvenes chilenos! -les exhortó- aprended a juzgar por vosotros mismos; aspirad a la independencia del pensamiento". ${ }^{14}$ Además, les advirtió que no hacerlo provocaría el desdén de los europeos: "La América no ha roto aún sus cadenas; sigue nuestras huellas con los ojos vendados; no hay en sus obras un pensamiento independiente, nada original, nada propio; imita las formas de nuestra filosofía, sin comprender su espíritu. Su civilización es una planta exótica que todavía no ha absorbido la savia de la tierra que la sustenta". ${ }^{15}$

Advirtiendo el peligro de irse al otro extremo y caer en un burdo nativismo, Bello sostuvo que se podía aprender muchas cosas de Europa: "Leamos, estudiemos las historias europeas; observemos muy de cerca el rumbo y drama particular de cada una de ellas; aceptemos los ejemplos, las lecciones que contienen, que tal vez es lo último que se nos ocurre" ${ }^{16}$ No obstante, insistió en la necesidad de la creatividad mental y de la primacía de la Independencia:

13. Gazmuri, La historiografía chilena..., 81-85.

14. Bello, Selected Writings..., 183.

15. Ibíd., 184.

16. Ibíd., 182. 
En toda clase de estudios, es necesario transformar las opiniones de los demás en convicciones propias. Es solo de esta manera que se puede aprender una ciencia. Y es solo así que los jóvenes chilenos podrán apoderarse del manantial de conocimientos que ofrece la cultivada Europa y contribuir a ésta algún día, enriqueciéndola y haciéndola más hermosa. ${ }^{17}$

Bello y Lastarria, desconocidos a principios de los años 1840, fueron nombres familiares en los círculos intelectuales sudamericanos para fines de la década.

El segundo debate sobre cómo escribir la historia de las repúblicas sudamericanas se inició en Buenos Aires con la publicación de la Historia de Belgrano de Bartolomé Mitre en 1859. Obra de un periodista y político argentino que vivió y trabajó en Chile en los años 1840, planteó la tesis de que el general Manuel Belgrano fue el arquitecto y la personificación del movimiento independentista argentino. Sus implicaciones eran claras: primero, que este proceso había sido logrado en gran medida gracias a la intervención de las provincias costeñas, de donde Belgrano era originario; y, segundo, que la mejor manera de entender la historia argentina era a través del estudio de la vida de los grandes hombres, no de la gente común.

Como era de esperarse, los argentinos del interior, como Dalmacio Vélez Sarsfield, entre muchos otros, no estuvieron de acuerdo. Abogado prestigioso, periodista y figura pública notable, Vélez Sarsfield enjuició el contenido y método de la obra de Mitre. Con respecto al primer punto, sostuvo que la idea de que la independencia argentina se debía principalmente a las élites de la costa era un "juicio injurioso y calumnioso a los pueblos del Interior". ${ }^{18}$ En apoyo a su crítica, recopiló pruebas que, según él, demostraban suficientemente que, sin los aportes del interior del país, Argentina no habría podido alcanzar su libertad. En cuanto al método, hizo dos serias objeciones: que no se podía contar la historia de un país con solo identificar los personajes ilustrados porque la historia de los líderes y sus seguidores era indisociable; y, que la Historia de Belgrano estaba fundamentada principalmente en fuentes gubernamentales donde primaban las preocupaciones y acciones de las facciones en el poder, las luchas internas de las clases acomodadas y los intereses de la región costeña. Lo que faltaba era la historia del interior y de su gente. En conclusión, para Vélez Sarsfield el relato de Mitre era solo una "historia oficial" y "regional", mas no una historia de la Argentina. Para escribir esta última habría sido necesario ir más allá de los documentos ofi-

17. Ibíd., 174.

18. Dalmacio Vélez Sarsfield, “Rectificaciones históricas: general Belgrano-general Güemes". En Bartolomé Mitre, Estudios históricos sobre la Revolución Argentina: Belgrano y Güemes (Buenos Aires: Imprenta del Comercio del Plata, 1864), 218. 
ciales e investigar a fondo la cultura popular tal como se manifestaba en leyendas, costumbres y en la tradición oral. ${ }^{19}$

La respuesta de Mitre no se hizo esperar: si la historia de los líderes y sus seguidores son una misma cosa, argumentó que se debía privilegiar el estudio de los primeros, ya que estos moldean y orientan a las masas. Se burló de la idea de utilizar la cultura popular como fuente histórica, porque no existía ningún método conocido para evaluar su contenido cognitivo. Mientras las fuentes oficiales, tanto impresas como manuscritas, podían ser depuradas con el método crítico, no se podía hacer lo mismo con la historia oral. Por tanto, solo los documentos que habían pasado la prueba de autenticidad y veracidad podían ser considerados los cimientos de una historia confiable. En cuanto a la acusación de prejuicios basados en clase y región, Mitre los descartó. En su opinión, la tarea del historiador no era construir una narrativa exhaustiva de todos los actores sociales, sino solo de aquellos que tuvieran relevancia nacional. ${ }^{20}$ Las idas y venidas del debate continuaron hasta bien entrado el decenio siguiente y tuvieron un impacto más allá de las fronteras de Argentina.

El tercer debate también tuvo lugar en Buenos Aires a principios de los años 1880 y se ocupó de la tercera edición de la Historia de Belgrano que Mitre publicó en 1877. Aprovechando la crítica de Vélez Sarsfield formulada a principios de los años 1860, Mitre había hecho un extensa revisión de su obra para la nueva edición. Pese a este esfuerzo, el resultado no satisfizo y desencadenó una nueva y agria controversia. Esta vez el protagonista fue Vicente Fidel López, un abogado argentino e historiador aficionado, quien como Mitre había vivido en Chile en los años 1840. Frente a un trabajo que documentaba meticulosamente todos y cada uno de los detalles de una densa narrativa, López sostuvo que una historia repleta de hechos verdaderos podía, en su conjunto, ser totalmente falsa. Para él, no bastaba con examinar la veracidad de los datos individuales. Era de mayor importancia estructurarlos en una totalidad coherente cuyo significado sobrepasara la mera suma de sus partes. Según López, esto no se podía lograr con el método crítico. Lo que se necesitaba era un enfoque que fuese simultáneamente sintético y estético, algo semejante al trabajo del artista. Adelantándose a Hayden White, parecía proponer que el tratamiento de los eventos necesitaba algo semejante a los protocolos de la literatura. Solo este tipo de historia, mantuvo López, tenía la capacidad de captar la originalidad y plenitud de la vivencia históri-

19. Vélez Sarsfield, “Rectificaciones históricas...", 247-262, especialmente 227-288 y 233-235.

20. Mitre, Estudios históricos sobre la Revolución..., 3-16, 32-42, 47-61, 63-72, 73-85, 130133, 139-151. Para un reporte sobre este debate, véase Abel Cháneton, Historia de Vélez Sarsfield, vol. 2 (Buenos Aires: Editorial Universitaria, 1937), 478-482. 
ca de Argentina y, además, de atraer y cautivar al lector, implantando en su mente una vívida experiencia del pasado. ${ }^{21}$

$\mathrm{Al}$ igual que en otras ocasiones, la respuesta de Mitre fue inmediata. Estaba de acuerdo en que una obra histórica podría ser verídica en cada una de sus partes aunque falsa en su conjunto. No obstante, argumentó que eso sucedía precisamente cuando autores como López imponían a los materiales empíricos criterios de selección, arreglo e interpretación que no emanaban de los propios documentos. Admitió que la historia era en parte una obra de arte, pero "la unidad de acción, la veracidad de los personajes, el interés dramático, el movimiento, el colorido de las escenas... el espíritu filosófico y moral de la obra" debía derivarse de fuentes primarias previamente bien evaluadas. Hacer lo contrario permitiría la inclusión subrepticia de todo tipo de ideas preconcebidas y, con eso, la tergiversación de la autenticidad de la narrativa histórica. ${ }^{22}$ Mientras López trataba la escritura de la historia como si fuera una actividad artística, Mitre la concebía como una rama de la ciencia.

Los tres debates que acabo de reseñar fueron los que más resonancia tuvieron en el Cono Sur y en la periferia sudamericana a lo largo del siglo XIX. Llegados a este punto, unos breves comentarios sobre su impacto general me parecen pertinentes. Con respecto al primer debate, si uno examina las obras más notables que aparecieron en la segunda mitad del siglo en la Sudamérica de habla española, es claro que la mayoría de los historiadores de la región optó por el método ad narrandum de Bello. Una lista de los más importantes incluiría a Diego Barros Arana, en Chile; Bartolomé Mitre, en Argentina; Gabriel René Moreno, en Bolivia; Mariano Paz Soldán, en Perú; Federico González Suárez, en Ecuador; y José Manuel Groot, en Colombia. ${ }^{23}$ Aunque constituía una clara minoría, el lado ad probandum también contó

21. Vicente Fidel López, Debate histórico: refutación a las comprobaciones históricas sobre la historia de Belgrano, 3 vols. (Buenos Aires: Librería La Facultad de J. Roldán, 1921), 83-112 (vol. 1); 197-263 (vol. 2); 323-350 (vol. 3).

22. Bartolomé Mitre, Comprobaciones históricas: primera parte (Buenos Aires: Librería La Facultad de J. Roldán 1916), 11-15, 196-208, 347-368; Comprobaciones históricas: segunda parte (Buenos Aires: Librería La Facultad de J. Roldán 1921), 15-36, 387-390. Para un análisis más completo de este debate, véase Ricardo Rojas, "Noticia preliminar". En Mitre, Comprobaciones históricas: primera parte, IX-XXXIX.

23. Sus obras más importantes se presentan a continuación: Diego Barros Arana, Historia Jeneral de Chile, 16 vols. (Santiago: Rafael Jover Editor, 1884-1902); Bartolomé Mitre, Historia de Belgrano y la independencia argentina, 2 vols. (Buenos Aires: Editorial Universitaria, 1859); Gabriel René Moreno, Últimos días coloniales en el Alto Perú (Santiago: Imprenta Cervantes, 1896); Mariano Paz Soldán, Historia del Perú independiente (Lima: Imprenta A. Lemale, 1868-1874); Federico González Suárez, Historia de la República del Ecuador (Quito: Imprenta del Clero, 1890-1893); y José Manuel Groot, Historia eclesiástica y civil de la Nueva Granada (Bogotá: Imprenta a cargo de F. Mantilla, 1869-1870). 
con partidarios, siendo los más significativos: Vicente Fidel López, en Argentina; Manuel Bilbao, en Chile; y Sebastián Lorente, en Perú. ${ }^{24}$

A diferencia del debate de los años 1840, la discusión de los años 1860 entre el "personaje ilustrado versus el pueblo" no tuvo una influencia inmediata. Esto sorprende porque en aquella época los gobiernos sudamericanos, desde Venezuela hasta el Cabo de Hornos, estaban adoptando "reformas democráticas". Es posible, empero, que exista una explicación más sencilla: la agitación política interna y externa de los años 1860 que prevaleció a lo largo de la región impidió que los historiadores pudieran concentrarse en su trabajo. Sin embargo, una vez que se estabilizó la situación, el impacto del segundo debate se volvió evidente. Sin desatender la manera cómo Mitre manejaba los materiales fácticos, un grupo de historiadores de la región empezó a alejarse de una historia centrada en individuos para dar una mayor agencia a los actores colectivos: a la población en general o a grupos específicos. Vicente Fidel López en Argentina, Sebastián Lorente en el Perú y Gabriel René Moreno en Bolivia ilustran esta tendencia. ${ }^{25}$

Finalmente, el debate del decenio de 1880, sobre la controversia entre "ciencia versus arte", agregó una nueva dimensión a la reflexión de cómo se debería escribir la historia de las repúblicas sudamericanas. Si bien todavía no se ha examinado su impacto, la evidencia existente sugiere que fue significativo. Indiscutiblemente, el cientificismo de Mitre dominó la controversia hasta fines del siglo. Pero a partir de estos años, la perspectiva estética de López comenzó a ser reconocida. En mi opinión, una nueva generación de historiadores acogió parte de esta posición y la transformó en un movimiento de nacionalismo cultural en varios países. Algunos de sus mentores iniciales fueron Ricardo Rojas en Argentina, Nicolás Palacios en Chile, Ricardo Palma en el Perú y Franz Tamayo en Bolivia. ${ }^{26}$

Estos tres debates, y otros que se llevaron a cabo en el Cono Sur en la misma época, generaron posicionamientos casi dogmáticos atravesando las fronteras de los países sudamericanos, lo que permite cuestionar la manera

24. Vicente Fidel López, Historia de la República Argentina (Buenos Aires: Editorial Universitaria, 1883-1893); Manuel Bilbao, "La sociabilidad chilena", El Crepúsculo, n. 2 (Santiago, 1 de junio de 1844); y Sebastián Lorente, Historia de la civilización peruana (Lima: Imprenta Liberal, administrada por M. Fernández, 1879).

25. Las obras más representativas de este tipo son Vicente Fidel López, Les races aryennes du Pérou. Leur langue - Leur religion - Leur historie (París: A la libraire A. Franck, 1871); Lorente, Historia de la civilización....; y Moreno, Últimos días coloniales...

26. Ricardo Rojas, Historia de la literatura argentina (Buenos Aires: Edición de la Librería "La Facultad", de Juan Roldán y Cía., 1917-1921); Nicolás Palacios, Raza chilena (Santiago: Impr. y Litografía Alemana Gustavo Schafer, 1904); Ricardo Palma, Tradiciones peruanas completas (Madrid: Aguilar, 1957); y Franz Tamayo, Creación de la pedagogía nacional (La Paz: El Diario, 1910). 
tradicional de entender la escritura histórica de la región. Se ha acostumbrado a clasificar esta producción en términos de la identificación de sus "influencias externas": racionalistas, románticos, positivistas, discípulos de Ranke, vitalistas, marxistas y de otras tendencias. ${ }^{27}$ Sin embargo, los intercambios internos que aquí exploro, siguiendo a Colmenares y Barnadas, sugieren un desarrollo intelectual más endógeno que exógeno. No es cuestión de privilegiar lo primero sobre lo segundo. Ambos resultan importantes. Sin embargo, mientras lo segundo convierte a los historiadores sudamericanos en "imitadores", en cambio, lo primero permite que sean apreciados como "creadores", enfocados en un diálogo entre pares. Precisamente, este ensayo se propone resaltar este rasgo. No hay duda de que este diálogo tuvo lugar: historiadores procedentes de Uruguay, Bolivia y Paraguay mantuvieron correspondencia e intercambiaron fuentes primarias y secundarias con sus pares en Argentina y Chile, a lo largo de sus trayectorias intelectuales. Por su parte, los historiadores de Perú, Ecuador, Colombia y Venezuela mantuvieron un seguimiento estrecho de la producción histórica proveniente del sur, y viceversa. ${ }^{28}$ Con el paso del tiempo, el fortalecimiento de este intercambio no solo contribuyó a la creatividad sino que generó una sociabilidad intelectual, que aportó al desarrollo de la historiografía de diferentes maneras.

Entre 1840 y 1890, los historiadores habían trabajado desprovistos de una infraestructura propia y sin apoyo institucional. Ante la falta de archivos y bibliotecas bien dotados, se vieron en la necesidad de recopilar y organizar las fuentes en sus gabinetes particulares. Además, debido a la inexistencia de revistas especializadas, utilizaron los periódicos y revistas de interés general para publicar sus investigaciones. Por fin, puesto que la historia todavía no era una profesión, emplearon su tiempo o se ganaron la vida trabajando, al mismo tiempo, como periodistas, novelistas, educadores, políticos, ministros, diplomáticos, militares y hasta desempeñaron el cargo de presidente. Bajo estas circunstancias, los historiadores no contaron con los medios, materiales o normativos, para poner su trabajo al margen de interferencias ideológicas derivadas de su adscripción étnica, clase social, creencia religiosa, partido político, o del ubicuo modelo europeo.

Impulsados por los debates y el respaldo estatal, hacia finales del siglo XIX, comenzaron a crearse sistemáticamente sociedades, juntas, academias y otras entidades semejantes. Aunque algunas de estas aparecieron tempranamente, la mayoría surgió entre 1880 y 1920. Las más importantes, en orden cronológico, incluyen a las siguientes: la Sociedad Chilena de Historia y

27. Véase, por ejemplo, Edberto Óscar Acevedo, Manual de historiografía hispanoamericana contemporánea (Mendoza: Universidad Nacional de Cuyo, 1992).

28. Esta investigación está en curso. El ensayo es un informe preliminar de mis primeros hallazgos. 
Geografía (1839); el Instituto Histórico y Geográfico Nacional (1843), en Argentina; la Sociedad Geográfica y de Historia (1886), en Bolivia; la Academia Nacional de Historia (1888), en Venezuela; la Junta de Historia y Numismática (1893), en Argentina; la Academia Colombiana de Historia (1902); el Instituto Histórico del Perú (1904); la Academia de Historia del Perú (1906); la Sociedad Ecuatoriana de Estudios Históricos Americanos (1909) y la Academia Nacional de Historia (1920), en Ecuador; el Instituto Histórico y Geográfico del Uruguay (1915); y el Instituto Paraguayo de Investigaciones Históricas "Dr. Francia" (1937). Al mismo tiempo, los archivos nacionales inaugurados a principios de siglo fueron renovados y se organizaron nuevos a lo largo de la región: Argentina en 1821, Colombia en 1868, Bolivia en 1883, Chile en 1886, Paraguay en 1895, Venezuela en 1914, Perú en 1923, Uruguay en 1926 y Ecuador en 1938. ${ }^{29}$

A partir de la creación de un espacio propio, los historiadores aficionados empezaron a construir una comunidad epistémica más homogénea de la que anteriormente existía. Mientras el entorno cultural de los años anteriores atrajo a letrados de todo tipo, el nuevo reunía a gente cada vez más interesada en la historia. Una consecuencia de esto fue el surgimiento de acuerdos y desacuerdos sobre los problemas cruciales de la historiografía. Se desarrolló un consenso bastante amplio acerca de tres principios metodológicos: primero, la prioridad que se otorgaba a las fuentes primarias en las narrativas históricas; segundo, la necesidad de aplicar técnicas hermenéuticas tales como los métodos filológico y crítico para evaluar la autenticidad y veracidad de estas fuentes; y tercero, la necesidad de ver al producto final como algo inacabado, sujeto a revisiones constantes en cuanto a método y contenido. ${ }^{30}$

También hubo desacuerdos entre los historiadores. Estos se referían a las estrategias cognitivas que de mejor manera darían cuenta sobre la experiencia histórica de las nuevas naciones: "la historia narrativa o la historia interpretativa"; "la historia de los grandes hombres frente a la historia del pueblo"; "la historia científica versus la historia como arte". Es cierto también que en esa época se discutían desacuerdos similares en Europa y en otras partes del mundo. Empero, este hecho no constituía una prueba de que el compromiso intelectual de los historiadores sudamericanos fuera de naturaleza derivativa. De manera parecida a los debates desarrollados en el Cono Sur, estas discusiones se basaron en materiales históricos locales y respondieron a necesidades

29. Para los archivos nacionales, véase Roscoe R. Hill, The National Archives of Latin America (Cambridge: Harvard University Press, 1945).

30. Gustavo Prado, "Las condiciones de existencia de la historiografía decimonónica argentina". En Estudios de historiografía argentina, ed. por Fernando Devoto, Gustavo Prado y Julio Stortini, vol. 2, 66-69 (Buenos Aires: Biblos, 1999). En líneas generales, las observaciones de Prado acerca de la historiografía argentina se aplican al resto de Sudamérica. 
del mismo origen, todo lo cual apunta en la dirección de que los historiadores más destacados de la región hicieron un esfuerzo concertado de reunir un conjunto de herramientas apropiadas a su más urgente necesidad, a saber, comprender el traumático tránsito de colonia a nación.

Con esto no quiero descartar o desvalorizar la influencia de autores extranjeros. Siguiendo los consejos de Bello, los historiadores hicieron un esfuerzo considerable para aprender de aquellos. Aunque se debería añadir que sus lecturas fueron en gran medida selectivas. Deseosos de justificar la independencia de España y su predilección por la forma de vida republicana, por ejemplo, leyeron a los grandes historiadores de Roma como Tito Livio y Tácito, así como también a Barthold Niebuhr y a Theodor Mommsen. ${ }^{31}$ También se mostraron inquietos acerca del destino de la república en su propia época, particularmente de la conflictiva y tortuosa experiencia francesa. Por eso acudieron a las obras de François-Pierre Guizot y Jules Michelet en los decenios 1860 y 1870, y a Hippolyte Taine algunos años más tarde.

En su mayoría, sin embargo, los historiadores sudamericanos leyeron autores extranjeros en busca de método. Como muy pocos hablaban alemán no se conoció directamente la obra de Ranke, la cual fue traducida al español recién en el decenio de 1940. ${ }^{32}$ Mientras tanto, diferentes versiones del paradigma rankeano llegaron a través de varios caminos. Uno de ellos fue el positivismo histórico francés, que adoptó un carácter germánico a partir de $1870 .{ }^{33}$ Otro fue la publicación de varios libros sobre método que aparecieron a fines del siglo y que popularizaron una perspectiva derivada de Ranke, tales como Lehrbuch der Historischen Method (Manual para enseñar el método histórico) de Ernest Bernheim en 1889; la Introduction aux études historiques (Introducción al estudio de la historia) de C. V. Langlois y C. Seignobos en 1897; Les Principes fondamentaux de l'histoire (Los principios fundamentales de la historia) de Alexandru Dimitrie Xenopol en 1899; y Cuestiones modernas de historia de Rafael Altamira en 1904. ${ }^{34}$

El impacto del modelo alemán, empero, fue bastante efímero, porque en los dos primeros decenios del siglo XX surgieron modelos alternativos que

31. Para la formación intelectual de la primera generación de historiadores venezolanos, véase Lucía Raynero, Clío frente al espejo: la concepción de la historia en la historiografía venezolana, 1830-1865 (Caracas: Academia Nacional de la Historia, 2007). A lo largo de todo el siglo XIX había un interés generalizado en la Roma republicana entre los intelectuales de Sudamérica hispana.

32. Guillermo Zermeño Padilla, La cultura moderna de la historia: Una aproximación teórica e historiográfica, 2. ${ }^{\text {a }}$ ed. (Ciudad de México: El Colegio de México, 2004), 147-154.

33. Por ejemplo, la Revue historique de Gabriel Monod, fundada en 1876.

34. Julio Stortini, "La recepción del método histórico". En Estudios de Historiografía..., vol. 2, 75-100. 
resultaron más atractivos en las obras de Benedetto Croce, Karl Lamprecht, Oswald Spengler, Lucien Febvre, Marc Bloch y Karl Marx. Mientras Ranke limitaba la práctica del historiador fundamentalmente a la historia política, las otras metodologías apuntaban hacia una historia económica, historia social e inclusive total..$^{35}$ En respuesta a las necesidades de la época, la producción histórica en Sudamérica a partir de 1840 hasta fines del siglo había sido exclusivamente política. Esto empezó a cambiar en las dos primeras décadas del siglo XX cuando las cuestiones de la modernidad económica y social se volvieron una preocupación de la más alta prioridad. ${ }^{36}$

Más que nuevas variedades de historia, lo que realmente buscaban los historiadores en cuestión, durante la primera mitad del siglo XX, era un método propio. Al referir el programa de un grupo de historiadores argentinos alrededor de 1920, conocidos como "la nueva escuela", Rómulo Carbia escribía: "El objetivo de la Nueva Escuela es la creación de un modo de reconstruir los acontecimientos históricos que sea propiamente americano y, más específicamente, argentino, utilizando para este propósito investigaciones documentales y bibliográficas realizadas de acuerdo con los métodos más rigurosos de Bernheim [...] e infundiendo vida al pasado tal como lo propone Croce".$^{37}$ Simultáneamente, en Perú, en la periferia de la región, José Carlos Mariátegui armaba un nuevo marco investigativo amalgamando a Marx, Lenin, Georges Sorel y Antonio Labriola, pero adoptándolos a la realidad peruana. ${ }^{38}$ Según José Aricó, al hacerlo, Mariátegui no estaba manipulando modelos europeos, sino inventando el "marxismo latinoamericano". ${ }^{39}$ El caso argentino y el peruano no fueron esfuerzos aislados. Unidos por un creciente rechazo a las ideas norteamericanas y europeas, ${ }^{40}$ que fue acen-

35. México era el único país en América Latina donde el paradigma de Ranke tuvo un impacto duradero cerca del final de nuestro período. Véase Zermeño Padilla, "Capítulo 5". En La cultura moderna...

36. Véase, por ejemplo, Sergio Villalobos, "La historiografía económica en Chile: sus comienzos", Historia 10 (1971): 7-56.

37. Citado por Stortini, en "La recepción del método...", 96.

38. Sin ser historiador, sino más bien un ensayista, Mariátegui intentaba dar coherencia al pasado de Perú para entender mejor el presente y plantear un plan de acción para el futuro.

39. José Aricó, "Marxismo latinoamericano". En Diccionario de Política, dir. por Norberto Bobbio y Nicola Matteucci, 6. ${ }^{a}$ ed. (Ciudad de México: Siglo XXI, 1991), 950. Véase también José Aricó “Introducción”. En José Carlos Mariátegui, Mariátegui y los orígenes del marxismo latinoamericano, selección y prólogo de José Aricó (Ciudad de México: Pasado y Presente, 1978); y José Carlos Mariátegui, “Capítulo 5" y “Capítulo 6". En ibíd.

40. La imposición del "imperialismo de la libertad" de los Estados Unidos en el Caribe y América Central entre los años 1890 y 1930 enfurecía a los latinoamericanos. La matanza de la Primera Guerra Mundial, sin embargo, les convenció de que la racionalidad europea era bastante superficial. 
tuado por la Revolución mexicana (1910-1920) y la publicación de Der Untergang des Abendlandes (La decadencia de occidente) (1918) de Spengler, los latinoamericanos en general y los historiadores sudamericanos en particular estaban entusiasmados en buscar una identidad intelectual propia, a partir de 1920. No se trataba de una fuga hacia un nativismo estrecho y provinciano. Al contrario, el objetivo explícito era lograr una síntesis entre un método de lo particular de la América Latina y un metamétodo que contenga los principios de una disciplina histórica concebida como un saber universal.

Las iniciativas de la Nueva Escuela y las de Mariátegui no fueron solamente respuestas a los desafíos de la época; también fueron la continuación de una larga tradición. Era una continuación de los esfuerzos hechos por Mitre, Vélez Sarsfield y López en los años 1860 y 1870 para captar la originalidad de la experiencia histórica sudamericana. En segunda instancia, fueron una respuesta a las recomendaciones que Bello dirigió a los historiadores chilenos en el decenio de 1840, exhortándoles a buscar independencia y creatividad intelectuales. Por fin, el origen de este empeño se remonta a fines del siglo XVIII cuando, respondiendo a los ataques lanzados contra las Américas por autores europeos como el Conde de Buffon, Guillaume Raynal, William Robertson, Cornelius de Paw y otros, los escritores latinoamericanos de ese entonces defendieron a su tierra, sus sociedades y su cultura, inventando en el proceso lo que Jorge Cañizares-Esguerra denomina "epistemologías patriotas". ${ }^{41}$

\section{INVENTANDO NACIONES REPUBLICANAS, 1840-1910}

Los historiadores sudamericanos aprendieron a escribir historia no solo debatiendo cuestiones metodológicas, sino también publicando sobre sus propias naciones de manera perseverante. Puesto que dichas naciones todavía no existían, se puede decir, por un lado, que ellos las inventaron y, por el otro, que se convirtieron en historiadores escribiendo sobre ellas.

Adquirida la independencia de España, los habitantes de los países sudamericanos se propusieron crear un nuevo orden económico, social, político y cultural, todo lo cual requería la invención de nuevas identidades. Durante el período colonial tardío, según las circunstancias, la gente se identificaba con la dinastía de los Borbones, con la fe católica y, de manera más frecuente, con el terruño americano. Alternativamente, también se adscribían a una

41. Jorge Cañizares-Esguerra, "Capítulo 4". En How to Write the History of the New World: Histories of Epistemologies and Identities (Stanford: Stanford University Press, 2001). 
identidad étnica (andaluz, vasca, quechua, aimara, guaraní, africana, etc.), una clase social o una localidad. El problema fue que ninguna de estas identidades equivalía a alguna de las nuevas identidades nacionales. Se necesitaba algo nuevo, una identidad intermedia, ya no se apelaba a un sentido de pertenencia imperial o a una patria local; se necesitaba, por así decir, una patria mediana, como fueron los ejemplos de Argentina, Chile, Bolivia, entre otros. Empero, esto no era solo una cuestión de magnitud; sino también un problema de orden cualitativo: la nueva identidad tenía que ser republicana. Al inicio del siglo XIX, por tanto, los sudamericanos tuvieron que imaginar no solo una comunidad nacional, tout court, sino una que fuese también republicana. ${ }^{42}$ En esta tarea, los historiadores desempeñaron un papel crucial. Dada su gran propensión a la discusión, entablaron una serie interminable de debates sobre el tema, dos de los cuales se destacan en particular. El primero tenía que ver con la cuestión de los orígenes nacionales; y el segundo con el tipo de modernidad republicana que deseaban para sus respectivas comunidades. A diferencia del tema del método, que había sido debatido principalmente en el Cono Sur, la problemática de la identidad nacional fue, sin excepción, objeto de controversia en cada uno de los países de la región. Por esta razón, este acápite se apartará momentáneamente del modelo centro-periferia y revisará libremente el contexto sudamericano, para ilustrar los casos que mejor expresen los debates acerca de la identidad.

Los orígenes nacionales republicanos fueron rutinariamente discutidos en términos de "tiempo" y "espacio". Si bien estos aspectos aparecieron a menudo juntos, es útil tratarlos separadamente, ya que los argumentos planteados en cada caso fueron diferentes. Desde la perspectiva temporal, la controversia se dio entre "ruptura versus continuidad", mientras que desde la perspectiva del espacio, el conflicto se centró en "Europa versus Hispanoamérica".

Los "debates sobre el tiempo" tuvieron tres dimensiones: generacional, ideológica y geográfica. En relación con lo generacional, los historiadores que publicaron en la primera mitad del siglo XIX sostuvieron que la Independencia marcó el nacimiento de una nueva identidad, puesto que implicó un rechazo de la tradición cultural hispánica y la adopción de una visión republicana del mundo, inspirada principalmente en los modelos de los países del norte del Atlántico, como Francia, Gran Bretaña y Estados Unidos. En la segunda mitad del siglo XIX, una nueva generación de historiadores pensó

42. Investigaciones recientes han mostrado que se desarrollaron las identidades nacionales y republicanas al mismo tiempo con relaciones complejas entre ellas. Véase Anthony McFarlane y Eduardo Posada Carbó, eds., Independence and Revolution in Spanish America: Perspectives and Problems (Londres: University of London / Institute of Latin American Studies, 1998). 
de otra manera: atenuó su postura respecto al legado colonial y defendió su relevancia para la época republicana. Así, los orígenes nacionales republicanos podían remontarse al período colonial. Rafael Baralt en Venezuela, José Manuel Restrepo en Colombia y Manuel José Cortés en Bolivia son buenos representantes de la primera generación; mientras que Diego Barros Arana en Chile, Sebastián Lorente en Perú y Federico González Suárez en Ecuador encarnaban a la segunda. ${ }^{43}$

La expresión ideológica del debate entre "ruptura versus continuidad" tenía que ver con el enfrentamiento entre liberales y conservadores a lo largo de toda la región. En términos generales, los liberales condenaron los valores económicos, sociales, políticos y culturales hispanos, razón por la cual favorecieron la ruptura. No así los conservadores, quienes no solo apreciaban estos valores por sí mismos, sino que los consideraban indispensables para una organización estable de las nuevas repúblicas. Colombia es la que mejor ilustra este conflicto; un país donde la ideología desempeñó un papel muy importante en la definición de identidades, particularmente en la segunda mitad del siglo XIX. Satisfechos con el desarrollo del liberalismo en este país, José Antonio Plaza y José María Samper escribieron obras en defensa de esta tendencia y abogaron por una identidad nacional liberal. José Manuel Groot y Sergio Arboleda, en cambio, se opusieron a ella. En su lugar, insistieron en el fortalecimiento de una identidad conservadora, arraigada en valores hispanos, y en los de la Iglesia católica. ${ }^{44}$

La tercera y última dimensión de los "debates sobre el tiempo" fue de carácter geográfico. Esta vez los protagonistas eran los historiadores liberales, quienes tenían perspectivas diferentes sobre el tema de identidad, según el lugar desde donde escribieran. Por ejemplo, los del Cono Sur no percibieron la época colonial como una experiencia totalmente negativa. Condenaron el dominio de los españoles sin reservas, pero también reconocieron a sus

43. A continuación, las obras que ilustran los puntos de vista de la primera generación: Rafael Baralt, Resumen de historia de Venezuela (París: Imprenta de H. Fourier y Comp., 1841); José Manuel Restrepo, Historia de la Revolución en la República de Colombia (París: Imprenta y Fundición de Pinard por Guillame N. Lallement, 1826); y Manuel José Cortés, Ensayo sobre la historia de Bolivia (La Paz: Imprenta de Beeche, 1861). A continuación las obras equivalentes de la segunda generación: Mitre, Historia de Belgrano...; Barros Arana, Historia Jeneral...; González Suárez, Historia de la República...; y Lorente, Historia de la civilización...

44. Las obras del campo liberal eran las siguientes: José Antonio Plaza, Memorias para la historia de la Nueva Granada desde antes de su descubrimiento hasta el 20 de julio de 1810 (Bogotá: Imprenta del Neo-Granadino por Ramón González 1850); y José María Samper, Ensayo sobre las revoluciones políticas (París: Imprenta de E. Thuntot y Cía., 1861). Las obras del campo conservador eran las siguientes: Groot, Historia eclesiástica y civil...; y Sergio Arboleda y Pombo, La República en la América Española (Bogotá: s. r., 1868-1869). 
antepasados el haber construido sociedades democráticas incipientes en los márgenes del espacio colonial, por así decirlo, sociedades que comenzaron a florecer tan pronto se consiguió la independencia. Así, para autores como Bartolomé Mitre y Diego Barros Arana hubo rupturas y también continuidades, y con ambas la posibilidad de un porvenir próspero. Este optimismo no se dio en el norte de Sudamérica. Aquí, el pasado colonial no tuvo redención alguna. Por un lado, el rol de la metrópoli fue considerado totalmente negativo y, por otro, a diferencia de los colonos del Cono Sur, no lograron superar la condición estamental de sus respectivas sociedades. Por lo tanto, para los historiadores liberales norteños la continuidad no era una opción posible. El futuro de sus nacionalidades dependía de su capacidad de adoptar la modernidad del Atlántico del norte y sus componentes culturales y políticos. La mejor ilustración de esta postura se puede encontrar en las obras del colombiano José Manuel Restrepo. ${ }^{45}$

Los debates sobre el espacio proporcionaron una visión completamente diferente acerca de la cuestión de los orígenes. Para la mayor parte de los participantes en la controversia "Europa versus Hispanoamérica", las nuevas naciones eran y debían ser una extensión de Europa, al menos en términos culturales. Sin embargo, hubo unos pocos para quienes las verdaderas raíces culturales de los nuevos países se encontraban en tierra americana. Esta divergencia se condensó en la dicotomía "civilización versus barbarie", una fórmula que se utilizó ampliamente a partir de 1840. Los grandes defensores de la primera expresión fueron el argentino Mitre y el chileno Barros Arana; mientras que los defensores de la segunda eran el argentino Vicente Fidel López, el peruano Sebastián Lorente y el boliviano Jaime Mendoza. Cabe destacar que, para estos últimos, "la barbarie" no era una condición innata, sino la consecuencia de la explotación colonial, pues antes de la llegada de los europeos, varias civilizaciones habían prosperado en Sudamérica, como la Inca y Aymara. Estas civilizaciones paralizadas durante tres siglos, finalmente podrían movilizarse e incorporarse a una forma de vida republicana que amalgamaría lo mejor de Europa con lo mejor de Amerindia. ${ }^{46}$

En el tercer cuarto del siglo XIX, la cuestión de los orígenes comenzó a perder su importancia, a medida que nuevas preocupaciones se volvieron más apremiantes. Para una nueva generación de historiadores, esto tenía

45. Mitre y Barros Arana desarrollaron su perspectiva de autoestima en la Historia de Belgrano... e Historia Jeneral..., respectivamente. Para el pesimismo de Restrepo, véase su Historia de la Revolución...

46. La idea de que la América Hispana después de su independencia era descendiente de Europa se encuentra en Mitre, Historia de Belgrano..., y Barros Arana, Historia Jeneral... Sus opositores, al respecto, eran Vicente Fidel López, en Les races aryennes...; y Lorente, en la Historia de la civilización... 
que ver, de una u otra manera, con cómo afrontar la llegada de la modernidad en toda la región y cómo nacionalizarla.

El primer encuentro de los sudamericanos con la modernidad ocurrió, en las primeras décadas del siglo XIX, cuando emprendieron la tarea de organizar "la república ideal". Lo intentaron insistentemente hasta la década de 1860, momento en que cansados de no conseguirla optaron cada vez más por la república práctica, también conocida como la república posible. ¿Qué les llevó a este cambio? Más que un proyecto futurista, se trató de un esfuerzo para ponerse al día con los acontecimientos. En el último cuarto del siglo XIX, la región entera había comenzado a cambiar en términos económicos, sociales, políticos y hasta culturales. En cuanto a lo económico, la región pasó a vincularse a una economía internacional cada vez más integrada. En el plano social, las nuevas economías empezaron a generar nuevos ricos, pobres y sectores medios. En la política, por su parte, ocurría un cambio importantísimo: el concepto de la libertad dejó de ocupar un lugar preeminente en las agendas gubernamentales y fue reemplazado por los conceptos de orden y progreso. Por fin, acorde con una economía abierta y una sociedad civil en movimiento, la región pasó por un período de intenso cosmopolitismo, proceso que provocó una reacción nacionalista igualmente vigorosa. En este contexto, se invirtieron las prioridades. Entre 1830 y 1870, estos habían dado preferencia a la modernidad política, la que según se asumía engendraría avances económicos, sociales y culturales, e inclusive una nacionalidad republicana. En los años 1880, esta secuencia se invirtió y se privilegió la modernidad económica por encima de las otras, pues esta sería la nueva base de una modernidad que rebasaría lo material en pos de lo moral. Mientras tanto, como este proceso tomaría tiempo, el Estado haría su parte manteniendo la paz con mano firme: lo que explica por qué todos los países de la región adoptaron explícita o implícitamente el lema de "orden y progreso".

¿Qué forma tomó la búsqueda de identidad en estas circunstancias? Dando prioridad a las nuevas preocupaciones, se dejó de lado la cuestión de los orígenes y se comenzó una reflexión sobre el tipo de identidad nacional que requeriría la modernización material. Entre numerosos debates sobre este tema, los más persistentes fueron los que discutieron la dicotomía entre "orden y libertad" y la división racial de "blancos y no blancos".

Se ha sostenido que para los historiadores sudamericanos decimonónicos, una identidad republicana era tan importante como una identidad nacional. Prueba de ello es el feroz enfrentamiento que se dio en el período de 1890 a 1920, entre aquellos que dieron primacía al mantenimiento del orden, como medio para lograr el progreso, y aquellos que defendieron los derechos civiles individuales y el republicanismo clásico. Para los historiadores del "orden", los caudillos y dictadores del período eran, a la vez, una versión hispanoa- 
mericana de la soberanía popular, los guardianes necesarios en un período de transición, y los creadores de un nuevo orden económico y social. En cambio, para los historiadores de la "libertad", los caudillos fueron el obstáculo de todo progreso: lamentaron su presencia porque hicieron de la política un conciliábulo de lealtades personales y de facciones que impidieron el desarrollo de élites políticas, económicas y sociales y de proyectos verdaderamente nacionales. Si bien este enfrentamiento se llevó a cabo en toda la región sudamericana, fue en Venezuela donde se escribieron y publicaron obras de importancia regional. Empezando en los años 1890, Jesús Muñoz Tobar y Rafael Fernando Seijas se pronunciaron en favor del Estado de derecho y atacaron a dictadores como Guzmán Blanco y sus seguidores. Contra estos autores se levantaron José Gil Fortoul y Laureano Vallenilla Lanz, sosteniendo que la libertad no era algo que se podía lograr a través de leyes, ya que, fundamentalmente, la libertad era el producto del medio ambiente, la raza, el progreso material, las condiciones sociales y las preferencias culturales. Cesarismo democrático (1919) de Laureano Vallenilla fue la mejor expresión de esta línea de pensamiento. ${ }^{47}$

El debate "blancos y no blancos" fue una controversia sobre quienes eran calificados como los agentes "idóneos" para promover la modernidad en los países sudamericanos. Para la mayoría de los autores, los blancos eran los "portadores" evidentes de una nación moderna. En cuanto a negros e indios, estos últimos eran considerados un obstáculo que debía ser neutralizado o eliminado de alguna manera. El objetivo final era construir en América del Sur naciones similares a las europeas, tanto en términos biológicos como culturales. No obstante, hubo algunos autores, para los cuales el verdadero portador del gen nacional era el mestizo: la mezcla entre indios, negros y blancos. En lugar de identificarse con Europa, esta población estaba inventando una identidad propia que, a la vez, era hispanoamericana y moderna. Desde luego, la dicotomía entre "blancos y no blancos" tuvo un cariz diferente según la mezcla demográfica en cada uno de los países sudamericanos. El caso de Bolivia es particularmente relevante por su diversidad de razas y porque sus historiadores produjeron obras de importancia regional. Tentativamente primero y enfáticamente después, Alcides Arguedas sostuvo que los indígenas y mestizos eran un impedimento para la consolidación de la nación boliviana y su inserción en la modernidad. Para él, nacionalidad y progreso solo podían alcanzarse mediante una europeización racial y cultural del país. Jaime Mendoza, médico, abogado e historiador, pensó de manera diferente. Convencido de que la prosperidad económica, la libertad polí-

47. Los constitucionalistas eran: Jesús Muñoz Tobar, El personalismo y legalismo: estudio político (Caracas, 1890); y Rafael Fernando Seijas, El Presidente (Caracas, 1891). Para sus opositores, véase José Gil Fortoul, Historia constitucional de Venezuela (Berlín, 1907-1909). 
tica y la educación podían dar nueva vida al indígena boliviano y vigorizar a la población mestiza, Mendoza pronosticó que ellos serían los principales agentes de cambio en Bolivia. En las dos primeras décadas del siglo XX, el punto de vista de Arguedas fue dominante; solamente en los años 1930 y 1940 el mensaje de Mendoza ganó terreno de manera gradual. ${ }^{48}$

¿Cómo la escritura de las historias nacionales contribuyó a la caja de herramientas de los historiadores sudamericanos? De diversas maneras. Un ejemplo, entre otros, es lo que pasó con el concepto de nación. En vez de seguir al pie de la letra el historicismo europeo, que concebía a estas entidades como unidades orgánicas que se desarrollaban en el tiempo como mónadas sin ventanas, ${ }^{49}$ los historiadores sudamericanos empezaron a considerar las naciones como proyectos que, eventualmente, integrarían en un territorio determinado no solo a diversas localidades, regiones y clases sociales, sino también a etnicidades y civilizaciones en conflicto desde hace siglos. En consecuencia, la categoría inventada por los historiadores sudamericanos contaba por lo menos con tres dimensiones. Reconocía la existencia de una heterogeneidad radical a partir de la cual había que forjar una nueva entidad, así como los problemas prácticos que esto implicaba para los arquitectos de la nación. También identificaba las dificultades de transformar esta heterogeneidad en un objeto de conocimiento, debido a la diversidad de culturas, idiomas y razas; así como por la variedad de conflictos sociales que entrañaban, tales como la esclavitud, la servidumbre, la vida comunitaria indígena, la ciudadanía republicana, las brechas entre el sector urbano y el rural, y las relaciones entre el centro y la periferia. Por último, a pesar de todos estos problemas, el concepto de nación aspiraba a canalizar estas fuerzas centrífugas hacia un nuevo orden normativo, un orden que sería tanto republicano como democrático. Mientras que el concepto europeo de nación buscaba validación en sus orígenes y en su carácter orgánico, la versión sudamericana se remitía al futuro, tenía un núcleo utópico y dependía abiertamente de una buena ingeniería social.

Además de ofrecer un aporte metodológico, los historiadores sudamericanos contribuyeron también al proceso real de la formación nacional. Inexistente a principios de los años 1800, lo que he llamado la patria mediana

48. Las principales obras de Alcides Arguedas son: Vida Criolla (La Paz: Editor E. Córdova, 1905); Pueblo enfermo. Contribución a la psicología de los pueblos Hispano Americanos (Barcelona: Imprenta de la viuda de Luis Tasso, 1909); Raza de Bronce. Novela (La Paz: Editores González y Medina, 1919); e Historia general de Bolivia (La Paz: Arnó Hermanos, 1922). Jaime Mendoza defendió su tesis en El factor geográfico en la nacionalidad boliviana (Sucre: Imp. Bolívar, 1925); y El macizo boliviano (La Paz: Arnó, 1935).

49. Dipesh Chakrabarty, Provincializing Europe: Postcolonial Thought and Historical Difference (Princeton: Princeton University Press, 2000), 23. 
nació gracias a ellos. Los historiadores trabajaron largas horas en archivos personales y oficiales, a menudo inhóspitos estos últimos, para determinar las fronteras físicas de sus países. Inventaron una memoria colectiva repleta de héroes y hazañas para dar contenido histórico a la temporalidad republicana. Finalmente, al pasar de la historia política a la historia económica y social, en la primera mitad del siglo $\mathrm{XX}$, fueron los primeros en reconocer la "cuestión social", o sea el problema de la incorporación de los pobres, negros, indígenas y otros fuereños a un posible conjunto nacional. ${ }^{50}$

Como en otras partes del mundo, se usó y abusó de la historia nacional en el área sudamericana. Caudillos de toda calaña, partidos políticos, la Iglesia católica, los militares y los acaudalados se aprovecharon de la historia en una lucha interminable por hacerse del poder. Un buen ejemplo de este uso y abuso se encuentra en Venezuela, donde el dictador Juan Vicente Gómez y Vallenilla Lanz, el autor de Cesarismo democrático, colaboraron estrechamente para establecer y legitimar un régimen autoritario entre 1908 y $1935 .{ }^{51}$

La ideología desempeñó un papel crucial en la historiografía de la región. En realidad, permeaba todos los aspectos de la vida sudamericana a lo largo del siglo XIX. El ideario que prevaleció, justificó y orientó tanto las guerras de la Independencia como el proceso de formación nacional y la búsqueda de la modernidad, fue el liberalismo. Por tanto, no es de sorprenderse que, entre los años 1840 y 1900, la gran mayoría de los historiadores de la región tuvieran convicciones liberales. ${ }^{52}$ Tampoco debería sorprender, como ya mencioné en la introducción de este ensayo, que su trabajo expresara principalmente los intereses de su clase social y procedencia étnica. ${ }^{53}$ Aunque estas alegaciones no han sido estudiadas a fondo todavía, me parece que, seguramente, corresponden a la verdad. El hecho es que, a principios del siglo XX, la institución de la historia en Sudamérica no había desarrollado todavía los mecanismos e instrumentos necesarios para proteger la integridad del producto histórico. Esta tarea la abordó una nueva generación de autores a partir de los años 1920.

50. Para el papel desempeñado por la "justicia social" en la vivencia chilena, véase Villalobos, "La historiografía económica...", 16-32.

51. John V. Lombardi, Venezuela: The Search for Order, the Dream of Progress (Oxford: Oxford University Press, 1982), 260; y Nikita Harwich Vallenilla, "Venezuelan Positivism and Modernity", Hispanic American Historical Review 70, n. 2 (1990): 342-344.

52. Juan Maiguashca, "Latin American Historiography (excluding Mexico and Brazil): The National Period, 1820-1990". En A Global Encyclopedia of Historical Writing, ed. por Daniel Woolf, vol. 2 (Nueva York / Londres: Taylor \& Francis, 1998), 542-545.

53. Burns, "Capítulo 3". 


\section{PROFESIONALIZACIÓN DE LA HistORIA, 1920-1945}

$\mathrm{Al}$ retomar el modelo de centro-periferia se encuentra que el Cono Sur, particularmente en Argentina, fue donde se emprendió el primer gran esfuerzo hacia la profesionalización de la historia. Refiriéndose al estado general de la historiografía en este país, en la primera mitad del siglo XX Joseph Barager escribe: "el desarrollo de los estudios históricos en Argentina [...] durante el cuarto de siglo posterior a 1920 probablemente no fue superado ni igualado por ningún otro país de América Latina". ${ }^{54}$ Mis propias investigaciones al respecto confirman ampliamente esta apreciación, con la salvedad de que el esfuerzo de profesionalización en Argentina comenzó realmente diez años antes.

En efecto, en 1908, la Universidad de La Plata pidió a Ricardo Rojas y a Ernesto Quesada, dos destacados historiadores argentinos, que preparen informes sobre la manera en que las universidades europeas y norteamericanas enseñaban la historia y su investigación a un nivel avanzado. En La Restauración nacionalista (1909) Rojas ofreció un análisis de los logros que encontró en estos campos en las universidades en Francia, Alemania, Inglaterra, Italia, España y los Estados Unidos. Quesada, por su parte, viajó a Alemania y, después de visitar veintidós universidades, publicó La Enseñanza de la historia en las universidades alemanas (1910). Como veremos a continuación, a partir de estos años, la pedagogía de la historia se convirtió en el centro de atención de las universidades argentinas. En 1910, Rafael Altamira, reconocido intelectual español, introdujo la enseñanza de la metodología histórica en la Universidad de La Plata, a petición de su rector. Dos años más tarde, la Universidad de Buenos Aires creó una sección de historia dentro de su Facultad de Artes y contrató a Emilio Ravignani, para que se encargue de ella. En 1913, Ricardo Levene, joven docente de la Universidad de La Plata, publicó sus Lecciones de Historia Argentina, el primer texto escolar de la historia del país basado en una meticulosa investigación de fuentes primarias y secundarias. Luego en 1914, al hacerse cargo del Consejo Nacional de Educación, Leopoldo Lugones (poeta, historiador y educador), empezó a impulsar vigorosamente la enseñanza de la historia a todos los niveles. En 1916, Ricardo Rojas publicó La Argentinidad con un propósito explícitamente pedagógico. Sólidamente documentada, esta obra examinó por primera vez la historia argentina en su totalidad: tanto la de Buenos Aires como del

54. Joseph R. Barager, "The Historiography of the Rio de la Plata Area since 1830", Hispanic American Historical Review 39, n. ${ }^{\circ} 4$ (1959): 602. 
interior. La década culminó con el Movimiento de Reforma Universitaria de 1918, cuyo principal objetivo fue modernizar la enseñanza universitaria en todo el país. Como es de conocimiento general, este movimiento se extendió al resto de América Latina, especialmente a Chile, Perú, Venezuela, México y Cuba, y fue, a la larga, responsable de la difusión de este particular logro latinoamericano: el principio de la autonomía universitaria. Consagrado en la ley, este precepto protegía a la institución universitaria de las interferencias gubernamentales. A lo largo de los años, el cumplimiento de esta conquista ha tenido sus altibajos. Empero, existen pruebas de que en su conjunto ha garantizado el trabajo académico, incluyendo la investigación histórica. ${ }^{55}$

A comienzos de los años 1920, la enseñanza de la historia a nivel universitario en Argentina había avanzado notablemente. Ricardo Levene, Emilio Ravignani, Diego Luis Molinari, Rómulo Carbia, Luis María Torres, Ricardo Caillet-Bois y otros, todos pertenecientes a una nueva generación de historiadores amateur, aprovecharon la coyuntura para lanzar un movimiento que buscó profesionalizar a la historia. La Nueva Escuela, nombre con que se dio a conocer este grupo, no era un colectivo coherente con un manifiesto bien definido. Se trataba, más bien, de un grupo de individuos, a menudo en desacuerdo, que intentaba convertir a la historia en una disciplina académica, cada uno a su manera. ${ }^{56}$ Con este fin, animaron y participaron en una amplia gama de actividades como la capacitación de nuevos historiadores por medio de la creación de seminarios y cátedras de historia; la transformación de archivos administrativos en repositorios históricos; la edición, impresión y distribución de fuentes primarias prolijamente anotadas; la fundación de revistas especializadas; y la publicación de obras seminales que dieron prioridad a la investigación en archivos. Este frenesí de actividad no se limitó a Buenos Aires sino que se extendió hacia el interior del país. ${ }^{57}$

Este proceso llevó a un cambio cualitativo en el desarrollo de los estudios históricos en Argentina. Además de las innovaciones antes mencionadas, la Nueva Escuela creó una comunidad académica que logró organizar

55. Véase Leopoldo Zea, “La autonomía universitaria como institución latinoamericana". En La autonomía universitaria en México, vol. I (Ciudad de México: Universidad Nacional Autónoma de México, 1979), 317-334.

56. Para los orígenes de la Nueva Escuela, véase Rómulo Carbia, Historia crítica de la historiografía argentina (La Plata: Universidad de La Plata 1939), 157-165.

57. Para mayor información sobre la profesionalización de la historia en Argentina, véase Fernando Devoto, ed., La historiografía argentina en el siglo XX, 2 vols. (Buenos Aires: CEAL, 1993-94); Devoto, Prado y Stortini, Estudios de historiografía...; Nora Pagano y Martha Rodríguez, eds., La historiografía rioplatense en la posguerra (Buenos Aires: La Colmena, 2001); Fernando Devoto y Nora Pagano, eds., La historiografía académica y la historiografía militante en Argentina y Uruguay (Buenos Aires: Biblos, 2004); y Fernando Devoto y Nora Pagano, Historia de la historiografía argentina (Buenos Aires: Sudamericana, 2009). 
un espacio autónomo dentro y fuera de la universidad. Mientras que la comunidad surgida entre 1880 y 1910 había convocado a letrados aficionados de la historia, la nueva se propuso únicamente convocar a gentes con oficio. Otra característica de la nueva comunidad fue un esfuerzo sostenido por lograr autosuficiencia y autorregulación. Por consiguiente, las universidades empezaron a implementar una serie de medidas como pagar a los historiadores por su trabajo de docencia e investigación. Además, la nueva comunidad empezó a dotarse de criterios y reglamentos que servirían para evaluar la competencia en la docencia, la investigación y otras actividades que se consideraban parte de la nueva profesión. También, se buscó apoyar la tarea de profesionalización a través de subsidios del Gobierno o financiamiento del sector privado. Pruebas adicionales del cambio cualitativo del oficio del historiador se encuentran en la carrera profesional de Emilio Ravignani, probablemente el historiador más representativo del período. Aunque fue miembro militante de la Unión Cívica Radical, no hay rastro de sus opiniones políticas en su producción histórica. Evidentemente, para Ravignani era posible ser, a la vez, investigador académico y partidario de una causa política, puesto que si bien ambas cuestiones podrían tener algún vínculo, eran actividades muy distintas. En otras palabras, en la Argentina de la época ya existía un código de conducta que guiaba al historiador profesional y le protegía de los abusos de la ideología..$^{8}$

Desafortunadamente, el reinado de la Nueva Escuela en términos metodológicos, institucionales y productivos resultó efímero. Luego de haberse labrado un espacio a lo largo de la década de 1930 hasta inicios del decenio siguiente, ${ }^{59}$ declinó en adelante, marginado por el impacto de la Gran Depresión y el advenimiento de la inestabilidad política que trajo la dictadura, cuyos efectos perduraron durante varias décadas.

Lo sucedido en Argentina respecto a la profesionalización de su historiografía, se dio en menor medida en Chile y, en un grado aún menor, en el resto de los países sudamericanos. ${ }^{60}$ La tarea de organizar una comunidad

58. Barager, "The Historiography of the Rio...", 603.

59. Barager escribe: "El período de 1930 a 1945 bien podría denominarse la Edad de Oro en la historiografía argentina". Ibíd., 606.

60. Con las excepciones de Argentina y Uruguay, todavía no se ha estudiado la profesionalización de la historia. Existe información dispersa sobre este tema en las siguientes obras: para Chile, Gazmuri, La historiografía chilena..., vol. I; para Uruguay, Ribeiro, Historiografía nacional, 1880-1940...; para Bolivia, Josep Barnadas, Diccionario histórico de Bolivia, 2 vols. (Sucre: Grupo de Estudios Históricos, 2002); para el Perú, Manuel Burga, La historia y los historiadores en el Perú (Lima: UNMSM, 2005); y Alberto Flores Galindo, "La imagen y el espejo: la historiografía peruana 1910-1986", Márgenes 2, n. ${ }^{\circ} 4$ (1988): 55-83; para el Ecuador, Rodolfo Agoglia, Historiografía ecuatoriana (Quito: Banco Central del Ecuador / Corporación Editora Nacional, 1985); para Colombia, Jorge Orlando Melo, Historiografía colombiana: Realidades y 
especializada y autónoma de historiadores solo pudo ser retomada, con toda seriedad, en el último cuarto del siglo XX. Para ese entonces, empero, otras repúblicas de las letras habían surgido en Centroamérica, México y el Caribe. En este nuevo contexto, se desarrollaron dos polos de crecimiento: Argentina y México. Estos dos países son los espacios de mayor producción historiográfica en Hispanoamérica hoy.

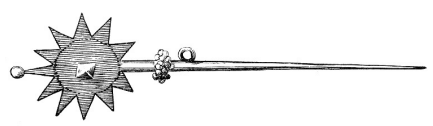

\section{FuENTES Y BIBLIOGRAFÍA}

\section{FUENTES PRIMARIAS}

Apu Shuaraura, Justo. Recuerdos de la Monarquía peruana o bosquejo de la historia de los Incas. París: Imprenta de J. Claye, 1850.

Arboleda y Pombo, Sergio. La República en la América Española. Bogotá: s. r., 1868-1869. Arguedas, Alcides. Historia General de Bolivia. La Paz: Arnó, 1922. . Pueblo enfermo. Contribución a la psicología de los pueblos Hispano Americanos. Barcelona: Imprenta de la viuda de Luis Tasso, 1909. . Raza de Bronce. Novela. La Paz: González y Medina, 1919. - Vida Criolla. La Paz: E. Córdova, 1905.

Baralt, Rafael. Resumen de historia de Venezuela. París: Imprenta de H. Fourier y Comp., 1841.

Barros Arana, Diego. Historia Jeneral de Chile. 16 Vols. Santiago: Rafael Jover Editor, 1884-1902.

Báez, Cecilio. Resumen de la Historia del Paraguay. Asunción: s. r., 1910.

Bauzá, Francisco. Historia de la dominación española en el Uruguay. 3 Vols. Montevideo: s. r., $1880-1882$.

Bello, Andrés. Obras completas. 26 Vols. Caracas: Ediciones del Ministerio de Educación / La Casa de Bello, 1981-1986. . Selected Writings of Andrés Bello, editado por Iván Jaksić. Oxford: Oxford University Press, 1997.

Bilbao, Manuel. "La sociabilidad chilena". El Crepúsculo, n. ${ }^{\circ} 2$ (Santiago: 1 de junio de 1844).

perspectivas (Medellín: Seduca, 1996); y para Venezuela, Germán Carrera Damas, Historia de la historiografía venezolana: Textos para su estudio, 3 vols. (Caracas: Universidad Central de Venezuela, 1997). No he podido encontrar una fuente confiable para el Paraguay. 
Carbia, Rómulo. Historia crítica de la historiografía argentina. La Plata: Universidad de La Plata, 1939.

Cortés, Manuel José. Ensayo sobre la historia de Bolivia. La Paz: Imprenta de Beeche, 1861.

González Suárez, Federico. Historia General de la República del Ecuador. 7 Vols. Quito: Imprenta del Clero, 1890-1903.

Groot, José Manuel. Historia eclesiástica y civil de la Nueva Granada. Bogotá: Imprenta a cargo de F. Mantilla, 1869-1870.

Lastarria, José Victorino. Bosquejo histórico de la constitución del gobierno de Chile durante el primer periodo de la revolución desde 1810 hasta 1814. Santiago: Imprenta Chilena, 1847.

Levene, Ricardo. Lecciones de historia argentina. 2 Vols. Buenos Aires: J. Lajouane, 1913, 1919.

López, Vicente Fidel. Debate Histórico: Refutación a las Comprobaciones históricas sobre la Historia de Belgrano. 3 Vols. Buenos Aires: Librería La Facultad de J. Roldán, 1921.

. Historia de la República Argentina. Buenos Aires: Editorial Universitaria, 18831893.

. La revolución argentina: Su origen, sus guerras y su desarrollo político hasta 1830.5

Vols. Buenos Aires: Imprenta y librería de Mayo, de C. Casavalle, 1881.

- Les races aryennes do Pérou. Leur langue - Leur religion - Leur historie. París: A la Libraire A. Franck, 1871.

Lorente, Sebastián. Historia de la civilización peruana. Lima: Imprenta Liberal, administrada por M. Fernández, 1879.

Mendoza, Jaime. El factor geográfico en la nacionalidad boliviana. Sucre: Imp. Bolívar, 1925.

. El macizo boliviano. La Paz: Arnó, 1935.

Mitre, Bartolomé. Comprobaciones históricas: primera parte. Buenos Aires: Librería La Facultad de J. Roldán 1916.

. Comprobaciones históricas: segunda parte. Buenos Aires: Librería La Facultad de J. Roldán 1921.

. Estudios históricos sobre la Revolución argentina: Belgrano y Güemes. Buenos Aires: Imprenta del Comercio del Plata, 1864.

. Historia de Belgrano y la independencia argentina. 2 Vols. Buenos Aires: Editorial Universitaria, 1859.

Moreno, Gabriel René. Últimos días coloniales en el Alto Perú. Santiago: Imprenta Cervantes, 1896.

Nicolás Palacios. Raza chilena. Santiago: Impr. y Litografía Alemana Gustavo Schafer, 1904.

Palma, Ricardo. Tradiciones Peruanas Completas. Madrid: Aguilar, 1957.

Paz Soldán, Mariano. Historia del Perú independiente. Lima: Imprenta A. Lemale, 18681874.

Pazos Kanki, Vicente. Memorias histórico-politicas. Londres: Impreso para el Autor, 1834. 
Plaza, José Antonio. Memorias para la historia de la Nueva Granada desde antes de su descubrimiento hasta el 20 de julio de 1810. Bogotá: Imprenta del Neo-Granadino por Ramón González, 1850.

Rojas, Ricardo. Historia de la literatura argentina. Buenos Aires: Edición de la Librería "La Facultad" de Juan Roldán y Cía., 1917-1921.

Ravignani, Emilio. Asambleas constituyentes argentina. 6 Vols. Buenos Aires: Talleres S. A. Casa Jacobo Peuser, 1937-1939.

Restrepo, José Manuel. Historia de la Revolución en la República de Colombia (París: Imprenta y Fundición de Pinard por Guillame N. Lallement, 1826.

Samper, José María. Ensayo sobre las revoluciones políticas. París: Imprenta de E. Thuntot y Cía., 1861.

Tamayo, Franz. Creación de la pedagogía nacional. La Paz: El Diario, 1910.

Vallenilla Lanz, Laureano. Cesarismo democrático. Caracas: Tipografía Americana, 1919.

Vélez Sarsfield, Dalmacio. "Rectificaciones históricas: general Belgrano-general Güemes". En Bartolomé Mitre, Estudios históricos sobre la Revolución argentina: Belgrano y Güemes. Buenos Aires: Imprenta del Comercio del Plata, 1864.

\section{BIBLIOGRAFÍA}

Adelman, Jeremy. Republic of Capital: Buenos Aires and the Legal Transformation of the Atlantic World. Stanford: Stanford University Press, 1999.

Acevedo, Edberto Óscar. Manual de la historiografía hispanoamericana contemporánea. Mendoza: Universidad Nacional de Cuyo, 1992.

Agoglia, Rodolfo. Historiografía ecuatoriana. Quito: Banco Central del Ecuador / Corporación Editora Nacional, 1985.

Barager, Joseph R. "The Historiography of the Rio de la Plata Area since 1830". Hispanic American Historical Review 39, n. ${ }^{\circ} 4$ (1959): 588-642.

Barnadas, Josep. Diccionario histórico de Bolivia. 2 Vols. Sucre: Grupo de Estudios Históricos, 2002.

. Gabriel René Moreno (1836-1908): Drama y Gloria de un Boliviano. La Paz: Altiplano, 1988.

Blaut, J. M. The Colonizer's Model of the World: Geographical Diffusionism and Eurocentric History. Nueva York: Guilford, 1993.

Bobbio, Norberto y Nicola Matteucci, directores. Diccionario de Política, 6. ${ }^{a}$ ed. Ciudad de México: Siglo XXI, 1991.

Burns, Bradford E. The Poverty of Progress: Latin America in the Nineteenth Century. Berkeley: University of California Press, 1983.

Burga, Manuel. La historia y los historiadores en el Perú. Lima: UNMSM, 2005.

Cañizares-Esguerra, Jorge. How to Write the History of the New World: Histories of Epistemologies and Identities. Stanford: Stanford University Press, 2001. y Erik R. Seeman, editores. The Atlantic in Global History, 1500-2000. Upper Sadle River: Pearson Prentice Hall, 2007.

Carrera Damas, Germán. Historia de la historiografía venezolana: textos para su estudio. 3 Vols. Caracas: Universidad Central de Venezuela, 1997. 
Chakrabarty, Dipesh. Provincializing Europe: Postcolonial Thought and Historical Difference. Princeton: Princeton University Press, 2000.

Cháneton, Abel. Historia de Vélez Sarsfield. Vol. 2. Buenos Aires: Editorial Universitaria, 1937.

Colmenares, Germán. Las convenciones contra la cultura: ensayos sobre la historiografía hispanoamericana del siglo XIX. Bogotá: Tercer Mundo / Universidad del Valle / Banco de la República, 1987.

Devoto, Fernando, editor. La historiografía argentina en el siglo XX. 2 Vols. Buenos Aires: CEAL, 1993-1994.

Devoto, Fernando y Nora Pagano. Historia de la historiografía argentina. Buenos Aires: Sudamericana, 2009. editores. La historiografía académica y la historiografía militante en Argentina y Uruguay. Buenos Aires: Biblos, 2004.

Flores Galindo, Alberto. “La imagen y el espejo: la historiografía peruana 1910-1986”. Márgenes 2, n. ${ }^{\circ} 4$ (1988): 55-83.

Fraga, Rosendo. "Argentina y Chile entre los siglos XIX y XX (1892-1904)". En Nueva mirada a la historia, editado por Esther Edwards, 143-165. Santiago / Buenos Aires: Ver, 1996.

Gazmuri, Cristián. La historiografía chilena, 1842-1920. Vol. I. Santiago: Centro de Investigaciones Diego Barros Arana, 2006.

Halperin Donghi, Tulio. Ensayos de historiografía. Buenos Aires: El Cielo por Asalto, 1996.

Harwich Vallenilla, Nikita. "Venezuelan Positivism and Modernity". Hispanic American Historical Review 70, n. ${ }^{\circ} 2$ (1990): 342-344.

Hill, Roscoe R. The National Archives of Latin America. Cambridge: Harvard University Press, 1945.

Jaksić, Iván. Andrés Bello: Scholarship and Nation Building in Nineteenth-Century Latin America. Cambridge: Cambridge University Press, 2001.

Johnson, Lyman L. y Zephyr Frank. "Cities and Wealth in the South Atlantic: Buenos Aires and Rio de Janeiro before 1960". Comparative Studies of Society and History 48, n. $^{\circ} 3$ (2006): 634-668.

Julien, Catherine. "Recuerdos de la monarquía peruana". Hispanic American Historical Review 84, n. 2 (2004): 344-345.

Larriqueta, Daniel. "Chile y Argentina: indianos diferentes". En Nueva mirada a la historia, editado por Esther Edwards, 111-126. Santiago / Buenos Aires: Ver, 1996.

Lombardi, John V. Venezuela: The Search for Order, the Dream of Progress. Oxford: Oxford University Press, 1982.

Maiguashca, Juan. "Latin American Historiography (excluding Mexico and Brazil): The National Period, 1820-1990". En A Global Encyclopedia of Historical Writing, editado por Daniel Woolf. Vol. 2, 542-545. Nueva York / Londres: Taylor \& Francis, 1998.

McFarlane, Anthony y Eduardo Posada Carbó, editores. Independence and Revolution in Spanish America: Perspectives and Problems. Londres: University of London / Institute of Latin American Studies, 1998.

Mariátegui, José Carlos. Mariátegui y los orígenes del marxismo latinoamericano, selección y prólogo de José Aricó. Ciudad de México: Pasado y Presente, 1978. 
Melo, Jorge Orlando. Historiografía colombiana: realidades y perspectivas. Medellín: Seduca, 1996.

Moya, José. "Modernization, Modernity and Trans/Formation of the Atlantic World in the Nineteenth Century". En The Atlantic in Global History, 1500-2000, editado por Jorge Cañizares-Esguerra y Erik R. Seeman. Upper Sadle River: Pearson Prentice Hall, 2007.

Pagano, Nora y Martha Rodríguez, editoras. La historiografía rioplatense en la posguerra. Buenos Aires: La Colmena, 2001.

Prado, Gustavo. "Las condiciones de existencia de la historiografía decimonónica argentina". En Estudios de historiografía argentina, editado por Fernando Devoto, Gustavo Prado y Julio Stortini. Vol. 2, 66-69. Buenos Aires: Biblos, 1999.

Raynero, Lucía. Clío frente al espejo: la concepción de la historia en la historiografía venezolana, 1830-1865. Caracas: Academia Nacional de la Historia, 2007.

Ribeiro, Ana. Historiografía nacional, 1880-1940: de la épica al ensayo sociológico. Montevideo: Ediciones de La Plaza, 1994.

Sáenz Quesada, María. "De la independencia política a la emancipación cultural". En Nueva mirada a la historia, editado por Esther Edwards, 91-105. Santiago / Buenos Aires: Ver, 1996.

Serrano, Sol. “Emigrados argentinos en Chile (1840-1855)". En Nueva mirada a la historia, editado por Esther Edwards, 111-126. Santiago / Buenos Aires: Ver, 1996.

Thomas, Jack Ray. Biographical Dictionary of Latin American Historians and Historiography. Westport: Greenwood, 1984.

- "The Role of Private Libraries and Public Archives in Nineteenth-Century Spanish American Historiography". The Journal of Library History 9, n. 4 (1974): 335-351.

Villalobos, Sergio. "La historiografía económica en Chile: sus comienzos". Historia 10 (1971): 7-56.

Zea, Leopoldo. "La autonomía universitaria como institución latinoamericana". En La autonomía universitaria en México. Vol. I, 317-334. Ciudad de México: Universidad Nacional Autónoma de México, 1979.

Zermeño Padilla, Guillermo. La cultura moderna de la historia: una aproximación teórica e historiográfica, 2. ed. Ciudad de México: El Colegio de México, 2004.

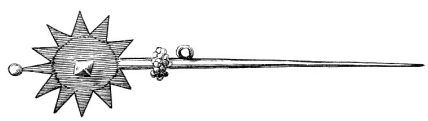

